\title{
RETHINKING USWAH HASANAH: Etika Dakwah dalam Bingkai Hiperrealitas
}

\author{
Farida Rachmawati \\ Alumni Pondok Pesantren Raudloh A-Tohiriyah Pati \\ Email: faridarachmawati08@gmail.com
}

\begin{abstract}
This paper aimed to discusses the activity of preaching (dakwah) as being part of the imaging world. The phenomenon is about dai as the advertisement representative from moslem fashion in media. The existence of media behind preaching makes it as a part of media industry. Therefore, consumerism appears as the excesses of capitalism intangible in a spectacle which no longer serves as a guide. This paper employs hyperreality theory of Jean Baudrillard to examine media constructions of reality beyond media. Media act as the bridge of communication in viewing the reality to bring the popular culture, consumerism, and consider it as significant image. We also compare the movement of preaching in media from uswah hasanah concept. However, the activity of preaching in the advancement of technology always faced with challenges, so its movement would be changing and should be adjusted without separated from the Islamic dakwah ethics. Therefore, dai as an actor in preaching does not be predominance by advertisement. Beside that, the important thing, that be supposed to give attention from dai and mad'u, is Islamic substantial not Islamic symbol.
\end{abstract}

$* * *$

Tulisan ini membahas tentang aktivitas dakwah yang menjadi bagian dari dunia pencitraan. Yakni tentang keberadaan dai sebagai agen atau bintang iklan sebuah busana muslim. Dengan adanya media yang berada di balik layar dakwah menjadikan dakwah bagian dari industri media. Sehingga tampak konsumerisme sebagai ekses kapitalisme yang berwujud pada tontonan yang tak lagi menjadi tuntunan. Teori hyperrealitas Jean Baudrillard digunakan untuk membaca konstruksi media terhadap realitas di luar media. Media mempunyai peran sebagai jembatan komunikasi dalam melihat realitas, sehingga mampu memunculkan budaya populer, sikap konsumerisme, dan menganggap penting citra. Di sini juga digunakan konsep uswah hasanah sebagai salah satu cara pandang terhadap fenomena dai media. Sebab bagaimanapun, aktivitas dakwah pada perkembangan teknologi sekarang ini selalu dihadapkan dengan berbagai perubahan, namun perubahan tersebut harus tetap disesuaikan dengan etika dakwah. Oleh karena itu, dai sebagai ujung tombak aktifitas dakwah jangan sampai didominasi oleh iklan. Selain itu juga diperlukan kesadaran baik dari dai ataupun mad'u agar tidak hanya mementingkan simbol Islam seperti formalisasi jilbab, tetapi juga memperhatikan substansi dari ajaran Islam.

Keywords: uswah hasanah, da'wa ethics, Islamic symbol, hyperreality 


\section{A. Pendahuluan}

Populasi muslim yang besar dan akan terus bertambah merupakan pangsa pasar yang menjanjikan. Paul Temporal, ahli pemasaran dari Said Business School, University of Oxford, memproyeksikan bahwa pasar muslim menjadi pasar alternatif setelah ekonomi Cina, Eropa, dan Amerika Selatan menurun. Ia meramal, jumlah orang Islam pada 2030 akan mencapai 2,2 miliar jiwa, naik $35 \%$ dari total populasi mulim sedunia sekarang. Jumlahnya akan terus bertambah hingga tahun 2050, ia memperkirakan total orang Islam secara global akan menyentuh angka 2,6 miliar atau $30 \%$ dari populasi manusia di bumi. Statistik tersebut menggambarkan betapa penting dan potensialnya umat muslim di masa mendatang.$^{1}$

Tingginya angka statistik populasi orang Islam dunia juga diiringi dengan mengeliatnya pasar middle-class moslem di Indonesia. Center for Middle Class Consumer Studies (CMCS) menyebutkan bahwa perubahan lima tahun terakhir pasar middle-class moslem mengalami revolusi, karena adanya perilaku yang sangat mendasar. Di antaranya: boom bank syariah, revolusi hijabers, kosmetik muslim yang kian digemari, biro travel umroh, kewirausahaan muslim seperti komunitas Tangan di Atas (TDA), pembayaran sedekah dan zakat, label produk halal, serta menggeliatnya produk budaya "bernuansa Islam" seperti buku ataupun novel Islami, aplikasi Islami, film Islami, musik Islami, termasuk juga dakwah Islam. ${ }^{2}$

Salah satu pasar muslim yang tengah berkembang pesat adalah industri busana muslim. Merujuk data Thomson Reuters dalam State of the Global Islamic Economy 2013 yang dimandatkan oleh Dubai Capital of the Islamic Economy, data tersebut menyebutkan posisi Indonesia berada pada ranking ketiga sebagai negara konsumen busana muslim terbesar senilai US $\$ 17 \mathrm{M}$ di tahun 2012. Sedangkan di urutan pertama dan kedua diduduki oleh Turki dan Iran. ${ }^{3}$

Para pelaku industri busana muslim pun tak menyia-nyiakan hal ini. Salah satu strategi mereka adalah menggunakan kekuatan brand ambassador (duta merek) dari kalangan selebritis ataupun dai untuk menciptakan tren baru sekaligus mendorong penjualan. Hal ini bisa jadi

\footnotetext{
${ }^{1}$ https://nururbintari.wordpress.com/2014/06/23/geliat-pasar-busana-muslim IslamicEconomy|Marcomm Cases in Indonesia diunduh pada 2/4/2015.

2 Yuswohandi, Marketing to The Middle Cass Moslem: Kenali Perubahannya, Pahami Perilakunya, Petakan Strateginya. Google books, diunduh pada 12 Januari 2015. hlm. 3-9

3 https://nururbintari.wordpress.com/2014/06/23/geliat-pasar-busana-muslimIslamic Economy|Marcomm Cases in Indonesia diunduh pada 2/4/2015.
} 
dipandang biasa karena dunia keagamaan (dakwah) dalam abad informasi dan virtual seperti sekarang, tidak dapat melepaskan diri dari pengaruh citra diri. Para dai bahkan menjadi trend dari model dan penampilan diri, sehingga di dalamnya berlaku relasi sosial yang mengikuti model budaya populer ${ }^{4}$, yaitu relasi antara patron (bintang, ustaz) dan client (massa, umat). Kegiatan ritual keagamaan digiring ke dalam perangkap artifisial ${ }^{5}$, sebagai cara menciptakan daya tarik dan keterpesonaan massa. Kegiatan keagamaan dimuati citra-citra tertentu yang bersifat profan ${ }^{6}$ yang sama sekali terlepas dari konteks kesucian ibadah. ${ }^{7}$

Di Indonesia, fenomena menggejalanya busana muslim di masyarakat sekarang ini semakin semarak dengan adanya beragam model dan pilihan. Misalnya, jilbab syar'i ala Ustazah Oki Setiana Dewi. Ada pula jilbab instan dan gamis (pakaian terusan) model Rabbani yang biasa dipakai sekaligus diperlihatkan Mamah Dedeh dalam setiap acara tausiyah paginya. Selain itu, pernah populer model baju muslim ala Ustaz Jeffry alBukhori atau Uje (almarhum). Ada pula Ustaz Soleh Mahmud (Solmed) yang juga menjadi duta merk Rabbani, dan sebagainya.

Pengaruh dai yang sering tampil di media -terutama televisi- dengan segala atributnya mampu untuk menarik perhatian para pemirsa. Apa yang masyarakat lihat tentang Oki Setiana Dewi, atau figur lain -dalam hal ini dai- di televisi dengan hijab dan pakaiannya hari ini, bukan tidak mungkin besok sudah ada di pusat-pusat grosir; Pasar Kliwon Kudus, Pasar Johar Semarang, Tanah Abang Jakarta, dan tempat lainnya. Terlebih sekarang juga telah berkembang pesat e-commerce atau bahasa mudahnya belanja online, yang semakin memudahkan hasrat masyarakat untuk berbelanja. Tingginya antusiasme masyarakat akhirnya tidak disia-siakan para produsen. Hal ini menurut Hermawan mengisyaratkan betapa media pada

${ }^{4}$ Istilah "populer", dalam sejarahnya merujuk pada standar estetik yang rendah dan rata-rata. Adorno mengategorikan budaya populer sebagai budaya rendah yang mempunyai kualitas, kreativitas, dan tingkat inovasi rendah yang sangat menggantungkan diri pada teknik reproduksi , repetisi, adopsi, dan imitasi (Piliang, 2014: 20-21). Lawan dari budaya populer adalah budaya nonpopuler yang biasanya disebut budaya luhur (Piliang, 2014: 177).

5 Dalam KBBI artifisial berarti sesuatu yang tidak alami, buatan.

6 Dalam KBBI profan berarti tidak bersangkutan dengan agama atau tujuan keagamaan; lawan dari sakral.

7 Yasraf Amir Piliang, Bayang-bayang Tuhan: Agama dan Imajinasi, (Bandung: Mizan, 2014), hlm. xli 
akhirnya merupakan agen utama yang menggiring nilai-nilai keterpesonaan massa yang cenderung berubah-ubah. ${ }^{8}$

Semaraknya kegiatan dakwah di berbagai media jika dilihat sepintas menimbulkan kesan bahwa dakwah telah meluas di masyarakat. Semua orang berpeluang menjadi pendakwah. Sehingga dakwah tidak terkesan monoton dan bisa dilakukan semua kalangan. Para dai media -khususnya televise- kemudian juga mengambil kesempatan tidak hanya mengisi acara tausiyah tetapi juga menjadi pemain sinetron, bintang film, bintang iklan atau brand ambassador sebuah produk baik kosmetik, pakaian, dan aksesori lainnya. Pada akhirnya perwajahan dakwah yang seharusnya dibingkai dengan ke-tawadhu'-an, kebijaksanaan, keihlasan, kesederhanaan jauh dari dakwah yang sebenarnya. Kehidupan mereka bahkan tak jarang menjadikan jarak dengan jamaahnya, terbukti dengan manajer yang senantiasa mengaturnya, sehingga uswah hasanah terhalang layar kaca. Hubungan dai dan jamaahnya berubah menjadi hubungan fans dengan artis idolanya. Puncak tujuan dakwah yang menghendaki perubahan sosial mengalami disorientasi, dan bukan tidak mungkin menjadi dakwah transaksional. ${ }^{9}$

Kegiatan keagamaan apabila telah menjadi bagian media, maka akan masuk ke logika media. Hubungan yang semestinya sakral turut menjadi bagian dari tontonan publik di berbagai media, sehingga logika media dan budaya massa ikut membentuk dunia kehidupan keberagamaan. Karena menjadi bagian dari masyarakat tontonan, agama tidak bisa dilepaskan dari trik-trik psikologis yang bertujuan membentuk daya tarik, eye catching, persuasi, dan keterpesonaan. Oleh karena itu, strategi keberagamaan menjadi sama dengan budaya populer..$^{10}$

Pengaruh budaya populer pada kehidupan keberagamaan menciptakan sebuah situasi dilematis. Di satu sisi, sifat-sifat kedangkalan dan permukaan budaya populer dapat mengancam sifat-sifat kedalaman agama. Di sisi lainnya, pendekatan populer memiliki kegunaan dalam komunikasi dan dakwah. Hal ini karena kemasan dakwah media dengan khalayak yang massal menghendaki penyampaian yang cenderung ringan dan mudah ditangkap. Lalu bagaimanakah seharusnya dai sebagai ujung

8 Anang Hermawan. "Televisi dan Budaya Instan”. Dalam Masduki dan Muzayin Nazaruddin (ed.), Media, Jurnalisme, dan Budaya Populer, (Yogyakarta: Prodi Komunikasi UII dan UII Press. 2008) hlm. 114.

9 Ahmad Sarbini, "Profesionalisme Dai Berbasis Tuhid". Asep Muhyiddin (dkk.), Kajian Dakwah Multiprespektif: Teori, Metodologi, Problem, dan Aplikasi, (Bandung, Remaja Rosdakarya, 2014), hlm. 64-65.

10 Yasraf Amir Piliang, Op.Cit, hlm. xli 
tombak pelaksanaan dakwah menyikapi perubahan era teknologi informasi, agar kegiatan dakwahnya tetap sesuai dengan etika dakwah Islam?

\section{B. Pembahasan}

\section{Dakwah dan Keteladanan}

Dakwah merupakan satu bagian yang pasti dalam kehidupan umat beragama. Dalam ajaran Islam, dakwah merupakan suatu kewajiban yang dibebankan oleh agama kepada pemeluknya. Sehingga dengan demikian, dakwah timbul dari pribadi atau golongan, walupun setidaknya ada golongan yang melaksanakannya. ${ }^{11}$

Menyampaikan dakwah di tengah masyarakat bukan sebatas tugas yang harus ditunaikan, akan tetapi lebih mencakup kepada pelaksanaan segala aspek dalam kehidupan. Dakwah tidak tergolong sukses pada diri seseorang, jika hanya diukur dengan kerajinannya berangkat ke masjid, pulang dari menunaikan ibadah haji, atau ikut hadir di hari besar Islam, seperti menghadiri pengajian maulid Nabi, dan sebagainya. Dai bisa disebut sukses apabila ia berhasil mengubah perilaku mad'u-nya, dalam segala aspek kehidupannya bukan hanya sekadar penampilan luarnya. Terkadang perubahan penampilan luar telah memberi kepuasan bagi sebagian dai. Hanya saja, cara ini telah jauh dari target utama dakwah di masyarakat. Lantaran tidak adanya amr ma'ruf nahy munkar secara merata dan bernilai signifikan. ${ }^{12}$

Dakwah sebagaimana pula yang dikemukakan M. Quraish Shihab merupakan seruan atau ajakan kepada keinsafan, atau usaha mengubah situasi kepada situasi yang lebih baik dan sempurna, baik terhadap pribadi maupun masyarakat. Perwujudan dakwah bukan sekadar usaha peningkatan pemahaman keagamaan dalam tingkah laku dan pandangan hidup saja, tetapi juga menuju sasaran yang lebih luas. Terutama pada masa sekarang ini, ia harus lebih berperan menuju kepada pelaksanaan ajaran Islam secara lebih menyeluruh dalam berbagai aspek kehidupan. ${ }^{13}$

Pengertian tersebut senada dengan apa yang diungkapkan alBayanuni terkait dakwah. Menurutnya dakwah mencakup tiga hal, yakni penyampaian (tabligh) ajaran Islam untuk manusia, memahamkan

11 M. Quraish Shihab, Membumikan Al-Qur'an, (Bandung: Mizan, 2007), hlm. 303

12 Fethulllah Ghulen, Dakwah: Jalan Terbaik dalam Berpikir dan Menyikapi Hidup, (Jakarta: Republika, 2011), hlm. 248

${ }^{13}$ M. Quraish Shihab, Op.Cit, hlm. 304 
(ta'līm/tazkiah), hingga penerapannya (tathbīq) dalam masalah-masalah kehidupan. ${ }^{14}$

Kesusksesan dakwah tak terlepas dari peran dai. Dai yang sukses dalam berdakwah adalah mereka yang ikhlas dan kuat keimanannya, jauh dari unsur kepentingan pribadi yang mengandalkan bentuk atau tampilan luarnya saja. Oleh karena itu, seorang dai harus mengendalikan segala tindak-tanduknya dalam hidup untuk menjadi teladan. Ia harus menyelaraskan antara perbuatan dan ucapan. Hal ini sebagaimana pernah Allah firmankan dalam surat al-Baqarah ayat 44, yang ditunjukkan kepada Nabi Isa As. dalam konteksnya sebagai penyampai risalah Allah.

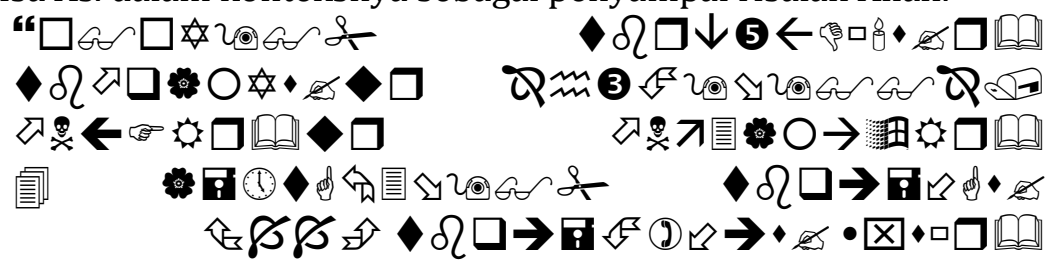

Mengapa kamu suruh orang lain (mengerjakan) kebaikan, sedang kamu melupakan diri (kewajiban) mu sendiri, Padahal kamu membaca Al-kitab (Taurat)? Maka tidaklah kamu berpikir?

Maksud ayat di atas merupakan ancaman keras bagi Bani Israil pada masa itu. Dan pelajaran yang bisa diambil oleh kaum muslim masa kini adalah larangan untuk memberi nasihat namun dirinya sendiri tidak melakukan apa yang disampaikan kepada orang lain. ${ }^{15}$

\section{a. Muhammad Saw. Sang Uswah Hasanah}

Muhammad Saw. tidak lain adalah keteladanan dan mencerminkan Alquran. Kata uswah berarti al-qudwah, yang mempunyai arti seseorang yang mengikuti orang lain. Keteladanan sendiri terbagi menjadi dua, yaitu keteladanan baik dan keteladanan buruk. Keteladanan yang baik yaitu seperti keteladanan yang terdapat dalam diri Rasulullah Muhammad Saw. Sedangkan keteladanan yang bertentangan dengan sifat Muhammad Saw. adalah keteladanan yang buruk. ${ }^{16}$

Muhammad Saw. adalah uswah (teladan) dalam sifatnya yang luhur. Adalah Alquran sendiri yang menegaskan dalam surat al-Ahzab ayat 21:

14 Muhammad Abu al-Fath Al-Bayanuni, Al-Madkhal Ila 'Ilm al-Da'wah. (Beirut: AlRisalah, 1993), hlm. 16-17

15 Fethulllah Ghulen, Op.Cit, hlm. 250-251

16Sa'd ibn Ali ibn Wahf al-Qahthani, Menjadi Dai yang Sukses, terj. Aidil Novia, (Jakarta: Qisthi Press, 2005), hlm. 312 


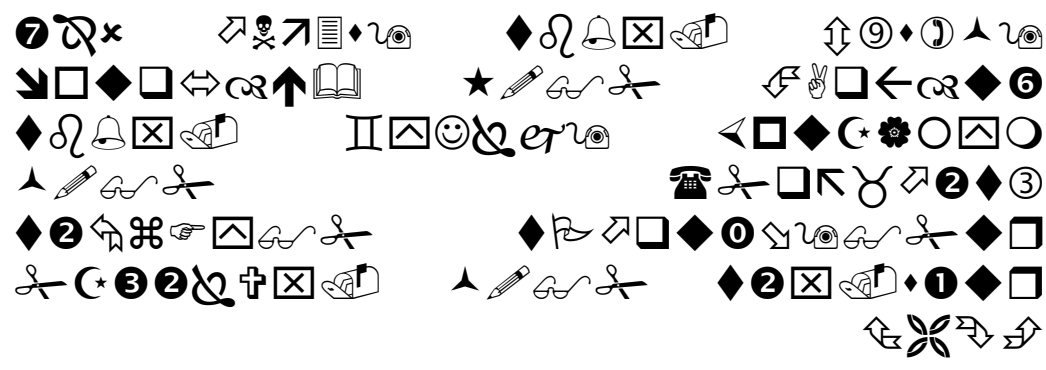

Sesungguhnya telah ada pada (diri) Rasulullah itu suri teladan yang baik bagimu (yaitu) bagi orang yang mengharap (rahmat) Allah dan (kedatangan) hari kiamat dan Dia banyak menyebut Allah.

Maksud ayat ini, sebagaimana yang dijelaskan Shihab kata uswah atau iswah berarti teladan. Pakar tafsir, az-Zamakhsyari, ketika menafsirkan ayat di atas, mengemukakan dua kemungkinan tentang maksud keteladanan yang terdapat dalam diri Rasul. Pertama, dalam arti kepribadian Nabi secara totalitasnya adalah teladan. Kedua, dalam arti terdapat dalam kepribadian Nabi hal-hal yang patut diteladani. ${ }^{17}$

Ayat ini walaupun berbicara dalam konteks Perang Khandaq, namun mencakup kewajiban atau anjuran meneladani Nabi walau di luar konteks tersebut. Ini karena Allah Swt. telah mempersiapkan Muhammad untuk menjadi keteladanan bagi semua manusia. Sesuai sabda Rasul "Addabanî Rabbî fa ahsana ta'dîbî" (Tuhan mendidikku, maka sungguh baik hasil pendidikanku). ${ }^{18}$ Ini menunjukkan keterbebasan Muhammad Saw. dari segala macam faktor pembentuk kepribadian. Bebas dari acuan dari bapak yang wafat sebelum Nabi lahir, bebas dari acuan ibu karena Nabi dibesarkan di desa yang jauh dari ibu. Di sisi lain, Nabi tidak mengenyam sekolah. Nabi juga bebas dari acuan lingkungan, karena bermukim dan diutus dari satu tempat yang relatif jauh dari peradaban. ${ }^{19}$

Banyak aspek keteladanan yang bersumber dari Nabi, baik sebagai Nabi dan Rasul, juga mufti dan hakim, di samping itu juga sebagai pemimpin masyarakat dan sebagai pribadi yang mempunyai beberapa kekhususan yang tidak boleh diteladani dan atau tidak harus diteladani. Sebab kekhususan Muhammad sebagai rasul, misalnya kebolehan menghimpun lebih dari empat istri, kewajiban salat malam, larangan

17M. Quraish Shihab, Op.Cit, hlm. 439

${ }^{18}$ Ibid

${ }^{19} \mathrm{Ibid}, \mathrm{hlm} .28-29$ 
menerima zakat dan sebagainya. ${ }^{20}$ Meski banyak aspek keteladanan Nabi, namun hal ini bukan tidak mungkin meneladani Nabi terutama bagi para dai.

Berikut ini beberapa hal yang menjelaskan pentingnya keteladanan dari segi amaliah yang baik, menurut al-Qahthani, ${ }^{21}$ dan hal ini yang hendaknya diperhatikan umat terlebih dai. Pertama, keteladanan dan contoh yang baik akan memberikan pengaruh yang besar pada diri seseorang yang berakal. Di antara pengaruh besar tersebut adalah seperti kesan yang baik, ketakjuban, penghargaan, dan kecintaan. Hal ini dapat mengantarkan orang lain untuk selalu berusaha melakukan tindakan orang yang diikutinya. Kedua, suri tauladan yang baik dengan dihiasi berbagai keutamaan bisa memberikan orang lain menerima, bahwa mengerjakan amalan saleh tersebut adalah sesuatu yang mungkin dan masih dalam koridor kemampuan manusia. Sebab, bukti yang terlihat lebih kuat dari pada bersumber dari ucapan belaka.

Ketiga, orang yang didakwahi oleh dai, akan memperhatikan dan mengamati secara mendalam segala perbuatan dan tingkah laku dai tanpa ia sadari. Sekiranya perbuatan dai tersebut menyalahi apa yang diucapkannya, maka hal ini akan menjadi malapetaka bagi dirinya sendiri. Terkadang seorang dai tidak menyadari dan tidak peduli kalau perbuatannya adalah kesalahan besar, sementara ia adalah orang yang diteladani. Maka firman Allah dalam surat Fushshilat ayat 33:

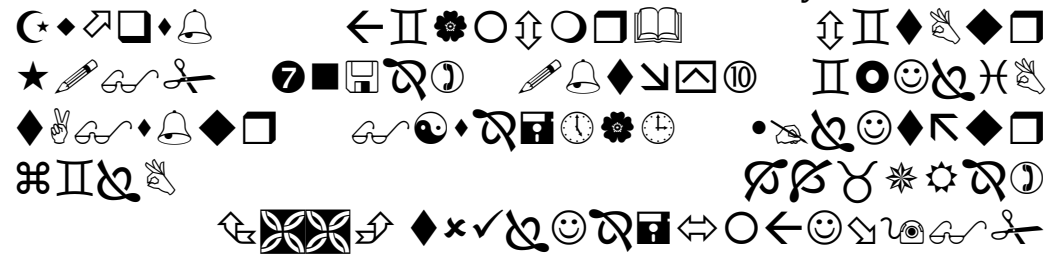

Siapakah yang lebih baik perkataannya daripada orang yang menyeru kepada Allah, mengerjakan amal yang saleh, dan berkata: "Sesungguhnya aku Termasuk orang-orang yang menyerah diri?"

Dalam ayat ini Allah menjelaskan supaya para dai melakukan perbuatan baik sesuai dengan apa yang diperintahkannya kepada orang lain, dan hendaknya ia berdakwah dengan perbuatannya. Sehingga dai yang baik tidak hanya secara lisan namun juga pada perbuatan. Berbeda

20 Ibid.

21 Sa'd ibn Ali ibn Wahf al-Qahthani, Menjadi Dai yang Sukses, terj. Aidil Novia, (Jakarta: Qisthi Press, 2005), hlm. 313-317 
dengan dai yang ucapannya tidak disertai dengan perbuatan, maka dakwahnya tidak akan mendapat rasa simpati dari orang yang didakwahinya.

Keempat, tingkat pemahaman masyarakat tentang sesuatu tidak sama. Namun sekilas, seolah-olah tingkat pemahaman manusia itu sama. Dengan demikian, hal ini akan mempermudah seorang dai untuk menyampaikan dakwahnya kepada orang lain yang akan mengikuti langkahnya. Misalnya tindakan Rasulullah yang memakai cincin emas, kemudian melepaskannya. Tindakan Rasul yang sedemikian itu kemudian diikuti oleh para sahabat dan umatnya yang lain. Hal ini menunjukkan perbuatan itu lebih besar pengaruhnya dari pada ucapan.

Kelima, Nabi Saw. memperingatkan para dai untuk tidak melanggar apa yang mereka katakan. Dalam sebuah hadis Nabi menjelaskan keadaan seorang dai yang menyeru kepada kebaikan dan mencegah kemungkaran, akan tetapi dai tersebut lupa terhadap apa yang mereka dakwahkan. Nabi bersabda, "Pada malam isra'ku, aku didatangkan kepada suatu kaum. Aku melihat lidah-lidah mereka dipotong dengan menggunakan gunting yang terbuat dari bara api mereka. Lalu aku bertanya, "Ya Jibril, siapakah mereka yang disiksa itu?" Jibril menjawab, "Mereka adalah para dai dari umatmu yang mengucapkan sesuatu, namun tidak melaksanakanya sendiri. Mereka membacakan ayat-ayat Allah, akan tetapi tidak melaksanakan kandungannya."

Keenam, orang yang diajak kepada kebenaran, di samping melihat segala perbuatan dan tingkah laku para dai (orang yang mengajaknya), mereka juga melihat keadaan keluarga dai. Sejauhmana keluarganya juga menjalankan apa yang ia dakwahkan. Hal ini menunjukkan bahwa seorang dai, di samping dirinya harus menjadi contoh yang baik bagi masyarakatnya, dia juga harus meluruskan dahulu para keluarganya dan mewajibkan mereka atas apa yang ia seru kepada orang lain. bahkan Umar bin Khattab r.a. setiap kali turun dari mimbar dan melarang sesuatu kepada khalayak, maka ia lalu mengumpulkan keluarganya dan berkata, "Sesungguhnya aku telah melarang manusia supaya tidak berbuat begini dan begitu, sesungguhnya mereka akan melihatmu seperti burung gagak meihat anak ayam. Aku bersumpah atas nama Allah, jika aku menemukan salah seorang di antara kalian melanggarnya, maka aku akan melipatgandakan hukumannya."

Beberapa sikap keteladanan Nabi yang bisa ditiru, di antaranya: tawadhu', sikap rendah hati atau tawadhu' dalam diri Nabi selalu tercermin dalam segala sesuatu. Nabi selalu menampilkan bahwa ia adalah manusia 
biasa. Nabi tak segan-segan membantu para sahabat saat membangun Masjid Nabawi atau ikut membangun parit saat perang khandaq. ${ }^{22}$

Nabi dan para sahabat juga tidak mementingkan perkara ibadah saja. Nabi sangat peduli kepada persoalan umat. Sebaliknya, meski urusan Nabi berkaitan dengan dunia dan seisinya, akan tetapi Nabi tetap tidak pernah melupakan seorangpun dari keluarga dan para sahabat. Nabi senantiasa meminta pertolongan Allah, agar senantiasa memberikan ampunan dan kemenangan bagi umat Islam sepanjang masa. ${ }^{23}$

Contoh Kesederhanaan Dai Masa Kini

Di tengah hiruk pikuk modernitas, keteladanan dai pada masa sekarang ini bisa jadi sebuah harga mahal. Di antara dai yang -bisa disebut masyhur- karena kemunculannya di tingkat nasional bahkan internasional, terdapat Gus Dur serta Gus Mus -K.H. Abdurrahman Wahid dan K.H. Ahmad Mustofa Bisri-. Dua dai ini berasal dari keluarga pesantren dan dikenal sangat bersahaja. Sebagaimana yang dituliskan Husein Muhammad dalam bukunya Gus Dur dalam Obrolan Gus Mus.

Gus Mus seperti juga Gus Dur dalam soal pakaian mereka biasa-biasa saja dan bersahaja. Padahal keduanya ulama dan kiai besar. Di banyak tempat Gus Mus sering atau bahkan selalu mengenakan baju putih, lengan panjang maupun pendek. Pecinya ada dua macam: warna putih khas orang baru pulang haji dan warna hitam khas Indonesia. Adapun Gus Dur bahkan sering tidak mengenakan peci. Sebab ukuran keagungan, keunggulan, kebesaran, kesalehan, dan karisma seseorang tidak diukur oleh lambang, aksesori berkilau, atau performa lahiriyahnya. Keagungan seseorang ditentukan oleh kebeningan hati dan tindakan baiknya. ${ }^{24}$

Tentang ukuran ketaqwaan seseorang tidak ditentukan oleh pakaian juga ditegaskan dalam firman Allah surat al-A'raf ayat 26:

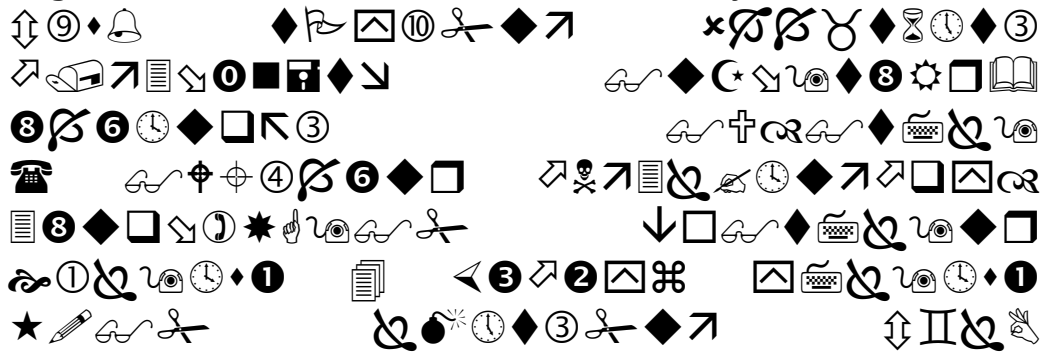

${ }^{22}$ Fethulllah Ghulen, Op.Cit, hlm. 268

${ }^{23}$ Ibid.

${ }^{24}$ Husein Muhammad, Gus Dur dalam Obrolan Gus Mus, (Bandung: Noura Books, 2015), hlm. 41-42 


\section{•ภ口ス2人 $\odot 0$}

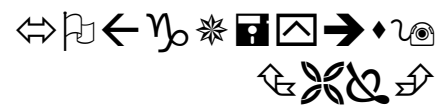

Hai anak Adam (manusia), Sesungguhnya Kami telah menurunkan kepadamu pakaian untuk menutup auratmu dan pakaian indah untuk perhiasan. dan pakaian takwa itulah yang paling baik. yang demikian itu adalah sebagian dari tanda-tanda kekuasaan Allah, Mudah-mudahan mereka selalu ingat.

Dari penjelasan di atas dapat dipahami bahwa ketaqwaan seseorang tidak diukur dari pakaian. Sedangkan keteladanan dalam konteks dai ini dimaksudkan agar tidak hanya mementingkan penampilan luar, karena pancaran kewibawaan dan kharisma dai tidak dari glamournya pakaian tetapi dari kesederhanaan. Selain itu mempertimbangkan aspek keteladanan dai yang dikhawatirkan menjadikan mad'u salah dalam meneladani sikap apabila dai mementingkan simbol pakaian.

\section{b. Etika Dakwah}

Ketika seseorang berinteraksi dengan orang lain, mustahil apabila tidak disertai dengan etika. Etika berasal dari bahasa Yunani, yaitu ethos yang berarti adat-istiadat (kebiasaan), perasaan batin, kecenderungan hati untuk melakukan perbuatan. Etika juga mengajarkan tentang keluhuran budi baik dan buruk. Jika dibatasi asal-usul kata ini, etika berarti ilmu tentang apa yang bisa dilakukan atau ilmu tentang adat kebiasaan. ${ }^{25}$

Etika dapat dirumuskan dalam empat poin sebagaimana berikut: (1) Etika dapat dipakai dalam arti nilai-nilai yang menjadi pegangan bagi seseorang atau suatu kelompok dalam mengatur tingkah lakunya. Misalnya, Etika suku Indian, Etika Agama Budha, Etika Islam. (2) etika berarti kumpulan asas norma tingkah laku, tata cara melakukan, sistem perilaku, tata karma, atau disebut juga kode etik. Misalnya, kode etik jurnalistik, kode etik guru, kode etik mubaligh. (3) etika mempunyai arti perilaku baik-buruk, boleh-tidak boleh, suka-tidak suka, senang-tidak senang. Etika ini semacam konsensus dalam masyarakat dan dilaksanakan bersama. (4) etika digunakan dalam ilmu, ilmu tentang perbuatan yang baik dan buruk. Etika baru menjadi ilmu bila disusun secara metodis dan sistematis yang terdiri dari asas-asas dan nilai-nilai baik dan buruk. Misalnya, seringkali masyarakat menjadi bahan referensi bagi suatu

25 M. Yatimin Abdullah, Pengantar Studi Etika, (Jakarta: Raja Grafindo Pustaka, 2006), hlm. 4 
penelitian etika yang disusun secara sistematis dan metodis mengarah pada filsafat etika. ${ }^{26}$

Pengertian etika secara terminologi (istilah), para ahli mempunyai pengertian yang berbeda-beda. Dalam M. Yatimin Abdullah disebutkan sebagai berikut:27 Ahmad Amin mengartikan etika sebagai ilmu yang menjelaskan arti baik dan buruk, menerangkan apa yang seharusnya dilakukan oleh manusia, menyatakan tujuan yang harus dituju oleh manusia dalam perbuatan mereka dan menunjukkan jalan untuk melakukan apa yang seharusnya diperbuat.

Franz Magnis Suseno mengaitkan etika sebagai usaha manusia untuk memakai akal budi dan daya pikirnya untuk memecahkan masalah bagaimana ia harus hidup apabila ia menjadi baik.

Burhanuddin Salam mengaitkan etika sebagai sebuah refleksi kritis dan rasional menyamai nilai-nilai dan norma moral yang menentukan dan terwujud dalam sikap dan pola perilaku hidup manusia, baik secara pribadi maupun kelompok.

Poedjawijatna mengaitkan etika sebagai ilmu yang mencari kebenaran. Ia mencari keterangan benar yang sedalam-dalamnya. Tugas etika adalah mencari ukuran baik buruknya tingkah laku manusia.

Lewis Mustafa Adam mengaitkan etika sebagai ilmu tentang filsafat, tidak mengenai fakta, tetapi tentang nilai-nilai, tidak mengenai sifat tindakan manusia tetapi tentang idenya.

M. Amin Abdullah mengaitkan etika sebagai ilmu yang mempelajari tentang baik dan buruk. Jadi etika bisa berfungsi sebagai teori perbuatan baik dan buruk (ethics atau 'ilm al-akhlak al-karimah).

Jadi menurut penulis, pengertian sederhana etika ialah suatu ilmu yang menjelaskan tentang perbuatan atau tingkah laku manusia, menerangkan apa yang seharusnya, mana yang dapat dinilai baik ataupun buruk yang dipedomani dan kemudian tercermin dalam amal perbuatannya.

Adapun konsep etika dalam Islam merupakan sebuah kesatuan yang tidak bisa dipisahkan. Tosihiko Izutsu menyebutkan bahwa Islam sebagai sebuah agama di mana kemunculannya merupakan reformasi agama yang paling radikal. Disebabkan kemunculannya di Arab pada abad ketujuh merubah pandangan masyarakat yang jahiliyah, kemudian menjadi periode

26 M. Yatimin Abdullah, Pengantar Studi Etika, (Jakarta: Raja Grafindo Pustaka, 2006), hlm. 4-6, lihat juga dalam Asep Muhyiddin, dkk. Kajian Dakwah Multiprespektif: Teori, Metodologi, Problem, dan Aplikasi. (Bandung: Remaja Rosdakarya, 2014), hlm. 200

${ }^{27}$ M. Yatimin Abdullah, Op.Cit, hlm. 7-9 
di mana moral mulai ditegakkan. ${ }^{28}$ Alquran sebagai sebuah tulisan paling autentik memuat konsep etik dan moral yang dapat dibagi menjadi dua kelompok utama. Pertama, terdiri dari istilah-istilah yang berkenaan dengan kehidupan etik orang Islam pada masyarakat Islamik (ummah). Kedua, istilah yang berkenaan dengan etika religius. Konsep pada kategori kedua membicarakan secara mendalam sifat esensial manusia sebagai homo religious. Konsep tersebut menurut pemahaman Qurani mencerminkan karakteristik spiritual tentang sifat manusia, dan manusia sebagai makhluk religius harus memahaminya. Dan menurut agama yang bersifat etik seperti Islam, karakteristik manusia harus menjadi religius dan sekaligus etik karena keduanya tidak ada perbedaan. ${ }^{29}$

Sistem etika Islam menurut Madjid Fakhri dalam Halimi dapat dikelompokkan ke dalam empat tipologi: pertama, moralitas skriptual, yaitu yang ditunjukkan dalam pernyataan-pernyataan moral Alquran dan sunnah yang analisisnya dilakukan para filsof atau teolog. Moralitas ini berisi tentang hakekat benar dan salah, keadilan dan keuasaan Tuhan, kebebasan dan tanggung jawab moral. Kedua, etika teologis, yakni prinsip benar dan salah, kemampuan tanggung jawab manusia dan kebijaksanaan serta keadilan Tuhan dalam diskursus mutakallimin. Hal ini terutama ditunjukkan oleh aliran Muktazilah. Ketiga, teori-teori etika filsafat yang berasal dari karya-karya etika Plato dan Aristoteles. Keempat, etika religius, yakni konsepsi etika yang berdasar dari konsepsi Alquran tentang manusia dan kedudukannya. ${ }^{30}$

Etika ketika diterapkan dalam sistem dakwah, ia menjadi orientasi bagi usaha dai untuk menjawab pertanyaan mendasar mengenai bagaimana seorang dai seharusnya hidup dan melaksanakan tugas profesionalnya. $^{31}$ Toha Yahya Omar mengemukakan beberapa etika berdakwah yang penting dimiliki oleh dai. Pertama, dai sedapat mungkin berlaku sopan. Sopan di sini berhubungan dengan adat dan kebiasaan yang berlaku umum dalam setiap kelompok. Sehingga ukuran kesopanan masing-masing kelompok berlainan satu dengan yang lain. Kesopanan meliputi pembicaraan dan perbuatan. Gaya atau perangai berbicara, cara mengenakan dan bentuk pakaian yang dipakai harus dijaga serapi-rapinya.

${ }^{28}$ Tosihiko Izutsu, Konsep-konsep Etika Religius dalam Qur'an, terj. Agus Fahri Husein, (Yogyakarta: Tiara Wacana, 1993), hlm. 19

${ }^{29}$ TIbid, hlm. ix

30Safrodin Halimi, Etika Dakwah dalam Prespektif Al-Qur'an, (Semarang: Walisongo Press, 2010), hlm. 40

${ }^{31}$ Hajir Tajiri, “Isu-isu Aktual Dakwah: Prespektif Etika" Asep Muhyiddin, dkk. Kajian Dakwah Multiprespektif: Teori, Metodologi, Problem, dan Aplikasi. (Bandung: Remaja Rosdakarya, 2014), hlm. 202 
Pembicaraan harus benar, tidak berbohong atau memutarbalikkan keaaan yag sebenarnya. Kedua, jujur terutama dalam mengemukakan dalil-dalil dan pembuktian. Kejujuran ini tidak hanya berlaku dalam dakwah bil lisan namun juga dakwah bil qalam. ${ }^{32}$

Sementara Hajir Tajiri mengemukakan beberapa hal penting yang harus dimiliki dai. Antara lain: pengenalan dan kesanggupan dai dalam mematuhi norma dan ketentuan dakwah, baik berupa norma teologis maupun norma sosial dakwah, pengenalan dan kesanggupan dai dalam mengimplementasikan kaidah-kaidah dakwah, serta pengenalan dan kesanggupan dalam meraih segi-segi keutamaan dakwah. Norma teologis maksudnya aturan-aturan yang berasal dari umber ajaran Islam Alquran dan hadis. Sedangkan norma sosial merupakan hasil buatan manusia sebagai makhluk sosial. Norma dalam masyarakat berisi tata tertib, aturan, dan petunjuk standar perilaku yang pantas atau wajar, seperti menyangkut tata cara (usage), kebiasaan (folkways), tata kelakuan (mores), adat (customs), dan hukum (lows).33

Adapun kaidah-kaidah dakwah yang harus dimiliki dai ialah berpedoman pada kaidah ushul fiqh seperti kaidah 'adam al-ikrah fi al-dîn (menghargai kebebasan dan menghargai hak individu atau kebebasan dalam beragama), al-dharuratu tubîhu al-mahdûrat (kondisi keterpaksaan membolehkan dilakukan hal-hal yang terlarang), al-tadarruj (gradual, mengikuti proses), dan sebagainya. Jum'ah Amin juga merumuskan beberapa kaidah seperti: al-qudwah qabla al-da'wah (menjadi teladan sebelum berdakwah), al-ta'lif qabla al-ta'rif (mengikat hati sebelum mengenalkan), al-ta'rif qabla al-taklif (mengenalkan sebelum membebani), al-ushul qabla al-furu' (perkara pokok sebelum cabang), al-targhib qabla altarhib (memberi harapan sebelum ancaman), al-tafhim la al-talqin (memberikan pemahaman bukan mendikte), al-tarbiyah la al-ta'riyah (mendidik bukan menelanjangi), tilmidzu al-imam la tilmidzu al-kitab (menjadi murid seorang guru, bukan murid buku). ${ }^{34}$

\section{c. Dakwah, Perubahan, dan Televisi: Tuntunan atau Tontonan?}

Salah satu prinsip agama yang merupakan aksioma adalah "segala sesuatu akan binasa, dan yang kekal selamanya hanyalah Tuhan.” Dalam

32Safrodin Halimi, Op.Cit, hlm. 41

33 Hajir Tajiri, "Isu-isu Aktual Dakwah: Prespektif Etika". Asep Muhyiddin, dkk., Kajian Dakwah Multiprespektif: Teori, Metodologi, Problem, dan Aplikasi. (Bandung: Remaja Rosdakarya, 2014), hlm. 203

34 Ibid 
bahasa Alquran prinsip tersebut antara lain dinyatakan dalam firman Allah surat al-Qashash ayat 88:

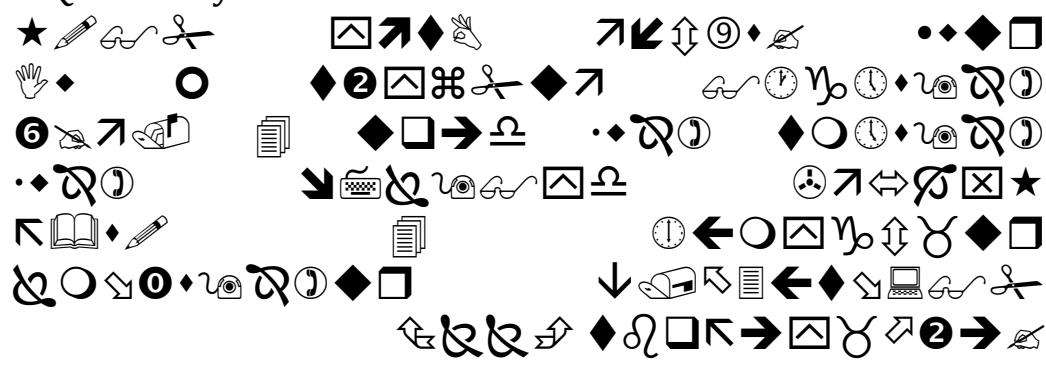

Janganlah kamu sembah di samping (menyembah) Allah, Tuhan apapun yang lain. tidak ada Tuhan (yang berhak disembah) melainkan Dia. tiap-tiap sesuatu pasti binasa, kecuali Allah. bagiNyalah segala penentuan, dan hanya kepada-Nyalah kamu dikembalikan.

Ayat di atas menjelaskan bahwa kekekalan hanyalah milik Allah. Maka hendaklah tiap manusia tidak menyembah kepada selain Allah.

Perubahan itu mencakup sesuatu, kecuali perubahan itu sendiri," demikianlah bunyi ungkapan lain. maksudnya bahwa perubahan merupakan keniscayaan bagi segala sesuatu; mengubah perubahan adalah mustahil. Alquran merupakan kitab pertama yang mengabarkan bahwa ada huku yang mengatur perubahan itu. Hukum tersebut dinamakan sunnatullah. ${ }^{35}$

Nurcholish Madjid menyebutkan bahwa tantangan dan kegairahan terhadap Islam merupakan fenomena Indonesia saat ini, dan semangat tersebut mendasari perlunya pemahaman terhadap Islam yang lebih baik. Paham pengkultusan yang tengah berkembang sekarang ini semua bertentangan dengan kebenaaran dan pencarian yang sebenarnya lebih mendalam tetapi menyejukkan, meyakinkan, dan pemahaman yang lebih berpendirian tentang makna dan tujuan hidup seperti yang terkandung dalam ajaran agama. Jawaban yang mudah dan singkat adalah kebutuhan jati diri dalam gemuruhnya lautan perubahan sosial yang cepat. ${ }^{36}$

35 M. Quraish Shihab, Tafsir al-Mishbah: Pesan, Kesan, dan Keserasian al-Quran, (Jakarta: Lentera Hati, 2002), hlm. 470

36Imron Rosyidi (ed.), Agama dalam Perkumpulan masyarakat Dunia, (Yogyakarta: Tiara Wacana, 1997), hlm. 123 
Pada era komunikasi massa yang dipengaruhi globalisasi media dan kapitalisme ekonomi. Hampir segala bentuk praktek komunikasi memiliki celah-celah bisnis. ${ }^{37} \mathrm{Hal}$ ini tidak terkecuali terjadi pada aktifitas dakwah terutama di media televisi yang keberadaannya -program dakwahsemakin semarak.

Di dalam pergumulan dai dengan media tentu saja niatan dai adalah syiar Islam, akan tetapi ketika berkaitan dengan ekonomi media, maka persoalan meluber kepada ekses ekonomi. Media mendapatkan pemasukan iklan dari program acara yang dijual, sebaliknya media harus pula membayar narasumber, dengan standar ekonomi media, yang didahului dengan kontrak. Suatu jenis kebohongan dalam teori komunikasi modern, jika orang yang bersentuhan dengan industri media sama sekali tidak memiliki tendensi ekonomi. Tentu saja mereka tidak bisa langsung dipersalahkan, sedangkan dai konvensional tetap menerima 'amplop' dari masyarakat. 38

Pada aspek dakwah Islam, salah satu yang menjadi 'bintang' adalah sang dai. Kegiatan dakwah yang mulanya sakral, intim, menjadi profan dan sebuah tontonan. Sebagai sebuah tontonan, penampilan tentu menjadi sesuatu yang sangat diperhatikan. Masyarakat terutama umat muslim menaggapi hal ini dengan antusias. Terbukti di tempat tinggal penulis di Kabupaten Pati telah banyak distributor merek busana muslim ternama yang keberadaannya merambah hingga ke Kecamatan bahkan perdesaan. Merek-merek tersebut sebagaimana yang penulis amati sering memberikan dukungan atau sponsor untuk acara tausiyah, di antaranya Mamah dan $A a^{\prime}$, ada juga sponsor yang mereka berikan untuk sinetron seperti Tukang Bubur Naik Haji, dan berbagai program lainnya. Salah satu penjual busana muslim dengan merek ternama ialah Lutfiyah (32 tahun) ${ }^{39}$ yang berasal dari Desa Mbajangan, Damar Wulan, Kabupaten Jepara. Pada saat lebaran ia menyediakan stok lebih banyak busana muslim, beberapa yang ia ambil ialah pakaian dengan merek ternama yang boleh dibayar dengan cara kredit. Di antara busana muslim ternama yang ia jual seperti Rabbani, Zoya, El-Zatta yang harganya untuk baju minimal seharga Rp 200.000 dan untuk jilbab minimal seharga Rp 45.000. Ia mengaku lebaran tahun 2015 di desanya sangat menjamur pakaian branded.

37 Ahmad Anas, Paradigma Dakwah Kontemporer, (Semarang: Pustaka Rizky Putra, 2006), hlm. 78

${ }^{38} \mathrm{Ibid}$, hlm. 79

39 Berdasarkan pemaparan dari Lutfiyah (masih saudara dengan penulis) saat lebaran Idul Fitri tahun 2015. 
Lembaga riset yang mengamati pasar muslim Indonesia, Center for Middle Class Consumer Studies (CMCS) melansir bahwa jumlah konsumen muslim di Indonesia mencapai angka 87 persen dari seluruh penduduk Indonesia. CMCS menyebutkan bahwa perubahan lima tahun terakhir pasar middle-class moslem mengalami revolusi, karena adanya perilaku yang sangat mendasar. Beberapa perubahan kasat mata fenomena menggeliatnya pasar middle-class moslem di Indonesia di antaranya: boom bank syariah, revolusi hijabers, kosmetik muslim yang kian digemari, biro travel umroh, kewirausahaan muslim seperti komunitas Tangan di Atas (TDA), pembayaran sedekah dan zakat, label produk halal, serta menggeliatnya produk budaya "bernuansa Islam" seperti buku ataupun novel Islami, aplikasi Islami, film Islami, musik Islami, termasuk juga dakwah Islam. 40

\section{d. Jean Baudrillard dan Teori Hiperrealitas}

Jean Baudrillard adalah seorang tokoh intelektual yang menghasilkan karya di bidang filsafat, teori sosial, dan budaya. Lahir di wilayah timur laut Perancis bernama Reims, pada tanggal 27 Juli 1929. Berkuliah di Sorbonne University dengan mengambil jurusan Bahasa dan Sastra. Setelah lulus dari Sorbonne University, ia mencoba karirnya sebagai seorang pengajar di berbagai sekolah di Perancis. Sembari mengajar, Baudrillard juga aktif menerbitkan ulasan sastra dan juga terjemahan karya ilmiah milik beberapa penulis seperti Peter Weiss, Friedrich Engels, Karl Marx, dan sebagainya. Pemikirannya terutama tentang konsep simulacra, hyperreality, dan ilmu simbolisme. ${ }^{41}$

Baudrillad memulai tulisannya dengan the System of Objects (1968), Consumer Society (1970) yang memperlihatkan pemikirannya banyak dipengaruhi paham Neo-Marxis tentang kritik terhadap kapitalisme. Ia kemudian secara perlahan meninggalkan paham Marxis dan tertarik ke pemikiran post-strukturalis seperti Faucault dan Derrida. Baudrillard menemukan bahwa kiasan produksi yang digunakan paham Marxis tidak tepat untuk memahami posisi komoditi di era setelah perang dunia.

40 Yuswohandi, Marketing to The Middle Class Moslem: Kenali Perubahannya, Pahami Perilakunya, Petakan Strateginya. (ttp.2014) Google books, diunduh pada 12 Januari 2015, hlm. 3-9

41 http://profil.merdeka.com/ mancanegara/j/jean-baudrillard diunduh pada 12 Januari 2015. 
Menurutnya, hanya semiologi (ilmu tentang tanda-tanda) yang dapat menjelaskan tentang komoditas secara modern. ${ }^{42}$ Misalnya:

$$
\text { Pepsi }=\text { anak muda }=\text { seksis }=\text { populer }=\text { kesenangan }
$$

Bahasa iklan tidak mengacu pada realitas, tetapi sebagai suatu koneksi arbiter dari penanda. Tujuan dari iklan adalah untuk mengasosiasikan suatu rantai penandaan di dalam suatu narasi dari sebuah gaya hidup yang diinginkan sebagaimana tampak dalam contoh di atas. ${ }^{43}$

Pemikiran Baudrillard senantiasa mengalami perubahan. Seperti pada karya Simulacra and Simulations (1981) merupakan teorinya tentang commodity culture (komoditas budaya). Budaya adalah sebuah simulacrum, sebuah salinan yang tidak asli, dan tidak memiliki referensi objektif. Baginya, budaya dewasa ini yang disusun oleh simulacra meningkat dan bersama-sama menyusun pola baru dari realitas yang disebut the hyperreal. Budaya terdiri dari atas realitas yang dikonstruksi (constructed realities), seperti Disneylands yang lebih nyata dari kenyataan. ${ }^{44}$

Baudrillard memusatkan tinjauannya pada hyperreal dan menolak pandangan modernis mengenai politik dan ekonomi sebagai sesuatu yang tidak bernilai. Citra dan realitas menurutnya tidak memiliki perbedaan status ontologis. Konsekuensi dari hal ini adalah kita kini hidup di dalam sebuah era yang Baudrillard menyebut sebagai salah satu dari simulacrum. Simulacrum merupakan konsep yang memiliki pemaknaan yang tidak berasal dari suatu perasaan pembedaan, tetapi dari jatuhnya ke dalam istilah-istilah yang pada era pendahuluan digunakan untuk membuat perbedaan penting bagi produksi pemaknaan. 45

Dari riwayat singkat Baudrillard yang telah dikemukakan, maka menunjukkan bahwa teori hiperrealitas digunakan untuk meneliti

42 Mark Poster. "Introduction". Mark Poster (ed.). Jean Baudrillard: Selected Writings. Diunduh dari http://www.humanities.uci.edu/mposter/books/Baudrillard,\%20Jean\%20\%20Selected\%20 Writings.ok.pdf pada 12 januari 2015. hlm. 1.

43 Antoni, Riuhnya Persimpangan Itu: Profil dan Pemikiran Para Penggagas Kajian Ilmu Komunikasi, (Solo: Tiga Serangkai, 2004) akses dari google books, diunduh pada 12 Januari 2015. hlm. 204

${ }^{44}$ Mark Poster. "Introduction". Mark Poster (ed.). Jean Baudrillard: Selected Writings. Diunduh dari http://www.humanities.uci.edu/mposter/books/Baudrillard,\%20Jean\%20\%20Selected\%20 Writings.ok.pdf pada 12 januari 2015. Hlm. 5-6. Lihat pula dalam Antoni, Riuhnya Persimpangan Itu: Profil dan Pemikiran Para Penggagas Kajian Ilmu Komunikasi, (Solo: Tiga Serangkai, 2004) akses dari google books, diunduh pada 12 Januari 2015. hlm. 205

45 Antoni, Riuhnya Persimpangan Itu: Profil dan Pemikiran Para Penggagas Kajian Ilmu Komunikasi, (Solo: Tiga Serangkai, 2004) akses dari google books, diunduh pada 12 Januari 2016. hlm. 205 
konstruksi media terhadap realitas di luar media. Bahwa media mempunyai andil dalam memengaruhi sikap, perilaku, dan pikiran seseorang sehingga memandang realitas media adalah realitas itu sendiri, yang kemudian melahirkan berbagai budaya populer, sikap konsumerisme, dan menganggap penting citra.

\section{e. Antara Hiperrealitas dan Hiperritualitas}

Perkembangan masyarakat kontemporer, yang dicirikan oleh kegandrungan pada budaya populer, budaya komoditas, gaya konsumerisme, dan permainan citra (image). Pada tingkat tertentu telah menyeret berbagai realitas ritual keagamaan (salat, puasa, zakat, lebaran, haji) ke dalam ruang-ruang pengaruhnya. Ketika ritual keagamaan terseret ke dalam ruang-ruang pengaruh tersebut (komoditas, konsumerisme, citra), maka akan terperangkap di dalam sifat-sifat kedangkalan dan artifisialitasnya, dan akan semakin menjauhkannya dari makna dan nilainilai hakikinya. Ketika berbagai aspek kegiatan ritual keagamaan tersebut secara hakiki tidak lagi berkaitan dengan model yang dicontohkan dan dalil-dalil yang telah digariskan, maka hal yang berkembang adalah apa yang disebut hiperrealitas ritual (hyper-reality of ritual) atau hiperritual (hyper-ritual), yaitu realitas ritual keagamaan yang telah melampaui hakikat ritual itu sendiri. Oleh karena itu, hal yang berkembang adalah berbagai bentuk realitas-realitas ritual artifisial. 46

Hiperritualitas adalah realitas yang telah terdistorsi dari realitas awal yang menjadi model atau rujukan -dalam Islam yakni Alquran dan Sunnah Nabi-. Ia menciptakan kondisi di mana tanda ritual (ritual signs) atau citra ritual (ritual image) dianggap sebagai realitas ritual seperti yang diajarkan Alquran dan Sunnah Nabi. Di dalamnya, antara bentuk kebenaran dan kepalsuan ritual, antara citra dan realitas ritual, menjadi tumpang tindih sehingga dua bentuk tersebut tidak dapat lagi dibedakan. Hiperritualitas membentuk semacam realitas kedua, yang referensinya adalah dirinya sendiri (simulacrum of simulacrum). Realitas artifisial yang diciptakan sedemikian rupa menjadikan pada tingkat tertentu tampak (dan dipercaya) sebagai bagian dari hakikat ritual keagamaan itu sendiri. ${ }^{47}$

Hiperritualitas mereduksi ibadah menjadi fenomena permukaan (surface), penampakan (appearance), dan tanda-tanda (signs), serta menjauhkan setiap orang dari makna terdalamnya, hakikatnya, dan nilainilai spiritualnya. Ritual direduksi menjadi simbol-simbol yang digunakan sebagai sebuah ungkapan kepuasan dan ketakwaan: baju koko, kopiah haji,

46 Yasraf Amir Piliang, Op.Cit, hlm. 320-321.

${ }^{47}$ Ibid, hlm. 322. 
sarung, jilbab, selendang penutup kepala, yang semuanya dibuat khusus dan hanya dipakai pada momen tertentu, seolah-olah identitas-identitas tersebut dianggap sudah cukup untuk merepresentasikan makna dan nilainilai ritual. 48

Hiperritualitas merupakan simbiosis antara kegiatan ritual keagamaan dengan budaya konsumerisme, gaya hidup, dan budaya populer. Ia membentuk hiperrkonsumsi (hyper-consumtion), yaitu konsumsi (makanan, pakaian, hiasan) yang melampaui nilai guna obyek, sebagai sarana pemenuhan fungsi utilitas (menghentikaan lapar, menutup aurat), yang kemudian dimuati dengan rangkaian tema, citra, dan suasana di luar nilai utilitas tersebut. Masyarakat konsumer atau masyarakat citra menjadikan kegiatan ritual keagamaan menjelma menjadi budaya konsumerisme. 49

\section{Refleksi: Penegakan Etika Dakwah di Era Artifisial}

Media dan berbagai penggerak dibelakangnya tentu tak akan membiarkan apa yang disebut sebagai 'kegairahan beragama'. Wujud kapitalisme yang 'menumpangi' dakwah salah satunya melalui tanda-tanda yang mendorong nafsu (nafs) untuk memenuhinya, yang kemudian menyebabkan perilaku konsumerisme. Dakwah yang mulanya tuntunan kemudian menjadi tontonan, karena visualisasi kamera yang indah dan dianggap sudah Islami.

Gejala yang terjadi pada beberapa dekade ini, umat muslim lebih mengedepankan penampilan atau dalam bahasa Baudrillard, citra. Hal ini terlihat sebagaimana riset dari lembaga Center for Middle Class Consumer Studies (CMCS) yang telah memetakan berbagai bidang yang kemudian berevolusi menjadi Islami, seperti bank dengan label syariah, kosmetik, dan produk budaya lainnya. Hal ini tentu tidak salah ketika umat berbondongbondong mengaktualisasikan Islam dalam berbagai aspek kehidupannya. Tetapi yang sangat disayangkan, ketika simbol artifisial (pakaian, kosmetik, dsb.) tidak dibarengi dengan perubahan perilaku menjadi lebih baik. Tentu saja menolong tetangga yang sedang kesulitan membeli beras misalnya, lebih utama daripada sekadar membeli lipstik dengan label halal.

Posisi dai sebagai salah satu unsur tercapainya sebuah tujuan dakwah tentu tidak bisa disepelekan begitu saja. Jika sekarang ini adalah zaman yang menuntut perluasan informasi berbasis teknologi, umat Islam

48 Ibid, hlm. 323.

49 Ibid, hlm. 324. 
pun harus serta merta menguasainya. Melalui dai, umat Islam harus tercerahkan karena inilah tugas inti dai dakwah ialah transformasi sosial. Meskipun masuk dan menjadi bagian dari media, hendaknya dai bisa mengontrol tugas dakwah yang diembannya. Di satu sisi mad'u sebagai penerima dakwah juga harus jeli dan cerdas dalam menerima informasi, agar tidak mudah terlena dengan penampakan-penampakan yang artifisial.

Islam yang pada dasarnya sebuah agama etik bukan tidak mempunyai landasan yang bisa menjawab tantangan modernitas ini. Keteladanan telah dicontohkan oleh Nabi Saw., salah satunya akan anjuran hidup sederhana. Kesederhanaan di sini bukan berarti akan menghilangkan kewibawaan atau menurunkan citra diri, justru akan menambah nilai diri. Apakah ada orang yang mengatakan bahwa kesederhanaan, ke-tawadhu'an Nabi menurunkan derajatnya sebagai manusia paling agung? Sangat disayangkan ketika tanda religius yang artifisial begitu diagung-agungkan, sedangkan nantinya akan datang masa kekekalan di mana hanya diukur dari ketaqwaan, sebagaimana yang ditegaskan-Nya dalam Alquran surat alA'raf ayat 26 bahwa "... Pakaian taqwa itulah yang paling baik...."

\section{f. Simpulan}

Dakwah sebagai bagian dari agama Islam tidak akan berhenti aktifitasnya hanya karena adanya perubahan. Perubahan khususnya yang terkait dengan perkembangan teknologi informasi -khususnya dalam hal ini; media televisi- tentu diharapkan dakwah bisa memasukinya. Aktifitas dakwah yang bersentuhan dengan media mau tidak mau akan masuk dalam lingkaran kapitalisme. Dalam pembacaan hyperrealitas, media mempunyai andil dalam mempengaruhi sikap, perilaku, dan pikiran seseorang sehingga memandang realitas media sebagai realitas itu sendiri. Sehingga kemudian dapat melahirkan berbagai budaya populer, sikap konsumerisme, dan menganggap penting citra.

Dai sebagai pelaksana dakwah seharusnya harus bisa membatasi dirinya agar tidak terlalu didominasi oleh iklan. Pendekatan dakwah dengan prespektif populer bisa menjadi pilihan tetapi ia membutuhkan tingkatan yang lebih lanjut. Sehingga dakwah yang seharusnya menjadi tuntunan tidak berubah hanya sebatas tontonan. Sebab jika dikembalikan ke makna asal dakwah, dakwah adalah usaha untuk implementasi nilai Islam di seluruh kehidupan. Mementingkan symbol saja tentu akan mendistorsi makna dakwah serta dari substansi Islam.

Dai sebagai ujung tombak aktifitas dakwah tentunya diharapkan menjadi uswah hasanah bagi mad'unya. Oleh karena itu dengan 
mengarahkan kembali dakwah sesuai dengan etika yang ada, dan mengingat bahwa dai adalah seorang uswah hasanah bagi mad'unya niscaya diharapkan tujuan dakwah akan tercapai. Etika ini tentunya tidak hanya dilihat sebagai nilai ideal yang tidak mungkin untuk diterapkan. Mengingat tantangan dan gerakan dakwah Islamiyah di negeri ini adalah bagaimana menyediakan dan mengembangkan basis etika yang akan mendukung pembangunan nasional, dan dalam kesempatan yang sama mampu memberi arah moral pembangunan nasional. Sehingga etika kemudian tidak hanya sebatas norma yang tidak berlaku atau sebagai sebuah kekangan. Namun lebih dari itu, etika menjadi sumber motivasi untuk melakukan hal-hal yang lebih baik. Wallahu a'lam bi al-shawab.

\section{DAFTAR PUSTAKA}

Abdullah, M. Yatimin, Pengantar Studi Etika, (Jakarta: Raja Grafindo Pustaka, 2006).

Al-Qahthani, Sa'd ibn Ali ibn Wahf, Muqawwimāt ad-Dā'iyah an-Nājih fi Dhau' al-Kitab wa as-Sunnah: Mafhum wa Nazhar wa Tathbîq, Terj. Aidil Novia, Menjadi Dai yang Sukses, (Jakarta: Qisthi Press, 2005).

Anas, Ahmad, Paradigma Dakwah Kontemporer, (Semarang: Pustaka Rizki Putra, 2006).

Antoni, Riuhnya Persimpangan Itu: Profil dan Pemikiran Para Penggagas Kajian Ilmu Komunikasi, (Solo: Tiga Serangkai, 2004).

Ghulen, Fethullah, Dakwah: Jalan Terbaik dalam Berpikir dan Menyikapi Hidup, (Jakarta: Republika, 2011).

Halimi, Safrodin, Etika Dakwah dalam Prespetif Al-Qur'an, (Semarang: Walisongo Press, 2010).

Hermawan, Anang. "Televisi dan Budaya Instan" dalam Masduki dan Muzayin Nazaruddin (ed.), Media, Jurnalisme, dan Budaya Populer, (Yogyakarta: Prodi Komunikasi UII dan UII Press, 2008).

Izutsu, Tosihiko, Konsep-konsep Etika Religius dalam Qur'an. Judul asli: Ethico-Religious Concepts in The Qur'an. Terj. Agus Fahri Husein, (Yogyakarta: Tiara Wacana, 1993).

Poster, Mark. "Introduction". Mark Poster (ed.). Jean Baudrillard: Selected Writings. Diunduh dari http://www.humanities.uci.edu/ mposter/ 
books/Baudrillard,\%20Jean\%20-\%20Selected\%20Writings.ok.pdf pada 12 januari 2015.

Muhammad, Husein, Gus Dur dalam Obrolan Gus Mus, (Bandung: Noura Books, 2015).

Piliang, Yasraf Amir, Bayang-bayang Tuhan: Agama dan Imajinasi, (Bandung: Mizan, 2014).

Rosyidi, Imron (ed.), Agama dalam Pergumulan Masyarakat Dunia, (Yogyakarta: Tiara Wacana, 1997).

Sarbini, Ahmad, "Profesionalisme Dai Berbasis Tuhid", dalam Asep Muhyiddin (dkk.), Kajian Dakwah Multiprespektif: Teori, Metodologi, Problem, dan Aplikasi, (Bandung: Remaja Rosdakarya, 2014).

Shihab, M. Quraish, Secercah Cahaya Ilahi: Hidup Bersama Al-Qur'an, (Bandung: Mizan, 2000).

Shihab, M. Quraish. 2002. Tafsir al-Mishbah: Pesan, Kesan dan Keserasian AlQur'an. Jakarta: Lentera Hati.

Shihab, M. Quraish, Membumikan Al-Qur'an, (Bandung: Mizan, 2007).

Tajiri, Hajir, "Isu-isu Aktual Dakwah: Prespektif Etika", dalam Asep Muhyiddin. dkk., Kajian Dakwah Multiprespektif: Teori, Metodologi, Problem, dan Aplikasi, (Bandung: Remaja Rosdakarya, 2014).

Yuswohandi, Marketing to The Middle Class Moslem: Kenali Perubahannya, Pahami Perilakunya, Petakan Strateginya, Google books, diunduh pada 12 Januari 2015.

https://nururbintari.wordpress.com/2014/06/23/geliat-pasar-busanamuslim-Islamic Economy|Marcomm Cases in Indonesia diunduh pada 2 April 2015.

http://profil.merdeka.com/mancanegara/j/jean-baudrillard diunduh pada 12 Januari 2015. 


\section{UCAPAN TERIMA KASIH}

Teriring syukur ke hadirat Allah swt, JURNAL ILMU DAKWAH volume 35 Nomor 2, Juli - Desember 2015 bisa kami terbitkan. Disamping itu terbitnya JURNAL ILMU DAKWAH kali ini juga berkat keterlibatan aktif para konsultan redaksi/mitra bebestari yang ikut serta menelaah naskah awal JURNAL ILMU DAKWAH. Mereka adalah:

1. Prof. Dr. H. Muhibbin, M.Ag. (UIN Walisongo Semarang)

2. Prof. Dr. Hj. Ismawati, M.Ag. (UIN Walisongo Semarang)

3. Dr. H. M. Nafis, MA. (UIN Walisongo Semarang) 
